\title{
INFORMATION AND COMMUNICATION TECHNOLOGY AND CREATIVE ECONOMY: A CASE FROM INDRAMAYU SUB DISTRICT
}

\section{TEKNOLOGI INFORMASI KOMUNIKASI DAN EKONOMI KREATIF: KASUS DI KECAMATAN INDRAMAYU}

\author{
Susri Adeni', Amiruddin Saleh ${ }^{2}$, Musa Hubeis ${ }^{3}$, Arif Satria ${ }^{2}$ \\ ${ }^{1}$ Graduate School, Bogor Agricultural University \\ ${ }^{2}$ Faculty of Human Ecology, Bogor Agricultural University \\ Jln. Kamper, Kampus IPB Dramaga Bogor, Indonesia \\ ${ }^{3}$ Faculty of Economic and Management, Bogor Agricultural University \\ Jln. Kamper, Kampus IPB Dramaga Bogor, Indonesia \\ susriadeni@yahoo.com
}

Submitted : March 31, 2019

Revised : April 26, 2019

Accepted : July 25, 2020

\begin{abstract}
ICT and the creative economy are growing rapidly in Indonesia. Coastal areas community have also began to use ICT, especially the internet. Women in coastal areas, with their creativity in processing fish catches to have economic value, should have used the internet in terms of expanding marketing. This research was conducted in Indramayu Regency, specifically Indramayu subdistrict, from October 2017 to January 2018.. The informants were coastal women who owned fish processing business. This study aimed to reveal how coastal women used their creativity in processing fish products and how they used the internet in order to expand their market share. The data obtained was processed qualitatively through data classification, data presentation and drawing the conclusion. The results indicated women's poor adoption of the internet. Only a few of them used the internet to market their products by using social media. This study concluded that ICT was not applied effectively in Indramayu subdistrict due to low literacy rates among women. Therefore, it is necessary to improve women's media literacy.
\end{abstract}

Keywords: Coastal Area, Creative Economy, Fish Production, Ict, Women

\begin{abstract}
ABSTRAK
TIK dan ekonomi kreatif berkembang pesat di Indonesia. Daerah pesisir pun juga mulai memanfaatkan TIK, khususnya internet. Perempuan di daerah pesisir, dengan kreativitasnya dalam mengolah hasil tangkapan ikan menjadi nilai ekonomi, seharusnya memanfaatkan internet untuk memperluas pemasaran. Penelitian ini dilakukan di Kabupaten Indramayu, khususnya Kecamatan Indramayu, mulai bulan Oktober 2017 hingga Januari 2018 dengan informan perempuan pesisir yang memiliki usaha produksi hasil olahan ikan. Tujuan penelitian ini adalah untuk mengetahui bagaimana perempuan di daerah pesisir menggunakan kreativitas mereka dalam mengolah ikan dan bagaimana mereka menggunakan internet untuk memperluas pangsa pasar mereka. Data yang diperoleh diolah secara kualitatif melalui tahap klasifikasi data, penyajian data dan penarikan kesimpulan. Hasilnya menunjukkan rendahnya tingkat adopsi internet di kalangan perempuan. Hanya beberapa dari mereka yang memanfaatkan internet untuk memasarkan produk dengan menggunakan media sosial. Kesimpulannya, TIK belum diterapkan secara efektif di Indramayu, karena rendahnya tingkat literasi perempuan nelayan di daerah tersebut. Oleh karena itu, penting kiranya untuk dilakukan usaha peningkatan literasi media bagi perempuan.
\end{abstract}

Kata Kunci: $\quad$ Daerah Pesisir, Ekonomi Kreatif, Perempuan, Produksi Ikan, TIK 


\section{INTRODUCTION}

Every year the growth of creative economy in Indonesia increases gradually. The creative economy sector contributes 7.13 percent to total national Gross Domestic Product (GDP). Of the 16 sub-sectors of creative economy, culinary, fashion and handicrafts are subsectors that contribute the highest value added (Gary, 2016). In the period of 2010-2015, the amount of creative economy rose from 525.96 trillion rupiahs to 852.24 trillion rupiahs. This means that there is an increase of around $10.14 \%$ per year in the GDP of the creative economy. This data shows that the creative economy has contributed significantly to the national development. Therefore, the government promotes the growth of the creative economy. In West Java Province, it contributed around $33.56 \%$ in 2017. It was the highest percentage among other provinces in Indonesia (Badan Ekonomi Kreatif, 2017).

In accordance with the creative economy development, the Information and Communication Technology (ICT) has also experienced rapid growth. The ICT discussed in this article refers to the internet. This is due to significant increase in the number of internet users in Indonesia. The number of internet users in 2017 has reached 143.26 million people; it is equivalent to 54.68 percent of the total population of Indonesia. This number shows an increase of 10.56 million people from the survey results in 2016 (Kominfo, 2018). In Indramayu Regency, based on 2018 census data in 31 subdistricts with 960 households, it was evident that $71.27 \%$ of the population used mobile phone and computer, $36.27 \%$ accessed the internet, and $57.18 \%$ had mobile phone. These data presented a great number of ICT users in Indramayu generally.
The term of ICT refers to various technology; it can be television, telephone, radio, satellite dish, internet and computers. In general, ICT is defined as "electronic means of capturing, processing, storing, and communicating information" (Gunnstam \& Nordquist, 2009). Meanwhile, according to Kwapong \& Adwoa (2007), ICT is as "a set of potential and instruction and instructional tools that can be used to help acquire people skills associated with traditional notions of literacy". From this understanding, it is clearly stated that whatever tools are used, the main function of this tool is to help people at work or other activities.

The pace of creative economy and the growth of ICT should be able to reach all levels of society; coastal women are no exception. It is because coastal women also have potential to increase family income and are expected to be able to use ICT in promoting the creative economy. Various research results show that women play an important role and make significant contribution to the family economy. However, women's role has not been fully supported by government policies (Hikmah, 2009). Discussing about gender and the technology, Hilbert (2011) clearly mentioned the reason why fewer women use and access ICT. It is due to the conditions of employment, education and income. Interestingly, he underlined that when women do not have adequate access to income, education and health, women are left behind in various fields especially ICT. However, if these three are prioritized for women, they will obtain gender equality in accessing ICT and have more opportunities to improve their quality of life. What Hilbert mentioned is largely supported by other literatures stating that women's 
limited use of ICT is related to income, education and employment.

Research about ICT and small-scale businesses as an integrated effort to alleviate poverty in Malaysia showed that computers are very useful because they are effective, more comfortable and able to store data and information. Therefore, Malaysian women acknowledge the fact and they agree to use computers in their work (Hashim et al., 2011). To a large extent, this is also the case in Indonesia. The high number of internet users in Indonesia shows a variety of functions that can be used by internet users. Women are also expected to reap positive benefits from ICT. Another research about the role of ICT to support the economic growth of fishermen was conducted in Kerala India (Gunnstam \& Nordquist, 2009). The ICT, especially the mobile phones used by the fishermen, increased the profit and at the same time lowered fish prices. Research conducted by Abiodun \& Sunday (2013) stated that selective use of ICT can be made to reduce the numbers of poverty rate. Therefore, it should be encouraged by the government. They also acknowledge that using information communication technologies (ICTs) for poverty reduction are more effective when their uses are embedded and synchronized with other policies and resources. This requires an enabling environment, which includes freedom of expression, competitive markets, independent regulators, a universal service fund and other elements, etc. In other words, ICTs alone without governmental incentives and community capacity will not work properly.

Meanwhile, in Indonesia, the role of ICT in poverty alleviation or small scale business is not known yet. A research conducted by Djauhari (2011) stated that initiatives to utilize the potential of ICTs to help government efforts to reduce poverty is rarely found. It can be said that there is a quite information about the role of ICT to decrease the number of poor community.

Exploring more about ICT and creative economy, especially in Indonesia and West Java, there are many people use various kinds of media from mobile phones to the internet. They are mainly used to fulfill the need for entertainment and information. However, in Indonesia, there are no studies that have comprehensively examined ICT in relation to the creative economy of women in coastal areas. Preliminary research results (February 2017) in the north coast region of West Java (Pantura), especially in Indramayu area showed that women in coastal areas have used smartphones connected to the internet, but the usage has not been optimised. They use the smartphones only for making a call and sending short messages.

The term 'creative economy' discussed throughout this paper refers to processed fish catches that have added economic value. Further discussion about ICT also emphasizes creativity in using it in all sectors of life. One of these is the increase of creative economy. Creative economy represents an economic concept in the new economic era that intensifies information and creativity by relying on ideas and stock of knowledge from Human Resources (HR) as the main production factors in its economic activities (Purnomo, 2016). The definition of creative economy according to 2009-2015 Indonesian Creative Economy Development Plan issued by the Indonesian Ministry of Trade in 2008 refers to individual's creativity (Afiff, 2012). Creative economy is a concept to realize sustainable economic development based on creativity (Purnomo, 2016). It is a utilization 
of resources that are not only renewable, but also limitless, namely ideas, talents and creativity. In addition, the economic value of a product or service in the creative era is no longer determined by raw materials nor production systems as found in the industrial era, but rather the use of creativity and the creation of innovation through increasingly advanced technological developments (Purnomo, 2016). Industries can no longer compete in the global market by only relying on prices or products. They must compete based on innovation, creativity and imagination.

According to the creative economy at the northern Java or Pantura, data shows that the Pantura region has high volume of fish production compared to other regions. Indramayu, which is located on the north coast of Java, has a higher production compared to other areas in the north coast. Here, fisheries products are commonly processed into meatballs, crackers, nuggets and others. Indramayu is very well known for its shrimp, milkfish, shrimp paste and fish paste. The volume of processed fish production increases every year in Indramayu. From 30,750.00 tons in 2014, rose to 40,181.00 tons in 2015 and 44,450.00 tons in 2016 (Dinas Kelautan dan Perikanan Jawa Barat, 2017). Interestingly, the fish processing is not only performed by men but also by women (preliminary research February, 2017). Women also work, as a part of their contributions to help improving their family economy and income. To improve the production, women should participate in creative economy activities using ICTs, including the internet (Nath, 2001).

Data also shows that women make a real contribution to family income. The growth of women's income contribution in West Java Province, according to the Central Bureau of
Statistics (BPS, 2017) was 1\% - 2\% from 2014 to 2015. The income contribution growth shows that in every region in West Java, women contribute to the family income. The significant contribution of coastal women to increase their family income might generate a creative economy through the use of ICTs. Unfortunately, women are left behind their male counterparts in using ICTs. Based on the facts above, this research formulated questions as follows: to some extent do coastal women use creativity in home-scale fish processing and to some extent do they use ICTs? This study aims to explore ICT usage and the creative economy in Indramayu, especially those carried out by coastal women.

\section{METHODS}

This research used qualitative approach, which collected data from observation and interview. The observation and interview were conducted with coastal women in Indramayu subdistrict, who run fish processing home industry to improve family welfare. Ten women, aged 30 to 45 years old, were interviewed to discover their activities related to creative economy and whether the internet was used as marketing tools of their product. The researcher interviewed the women and closely observed their fish processing activities. The research was conducted from December 2017 to January 2018. Besides observation and interview, literature review was also used by analysing theoretically about ICT and creative economy. The data received was analyzed in three steps: reduction, presenting and drawing a conclusion related to the research question.

\section{RESULT AND DISCUSSION}

Many literatures underline that ICT can improve the quality of human life (Tiwari, 
2008). In addition, ICT can generate many benefits for developing countries. New technology is the main tool for news and information dissemination. For instance, people living in rural areas use mobile phones to contact relatives who reside in other regions or locations (Obijiofor, 2015). This technology is expected to be able to assist people's life. Internet is used by many people nowadays to sell their products so that it is popular as online market. People can buy things by ordering products from a website or social media then they transfer the money to have the product they buy.

Those various research result also occurred in the locus of this research, Indramayu subdistrict. Most women use smartphone to get connected with their customers, as being discussed below.

People who live in coastal areas also benefit from ICT. In this study, the term 'ICT' specifically refers to the internet. Most of women in Indramayu subdistrict connect to the internet using smartphone. They are also aware of social media such as WhatsApp, Facebook dan Instagram. This knowledge is further examined by researcher in order to find out more about the use of internet for the informants in selling their products.

This study was conducted in Indramayu Regency, which is located in the northern coast of West Java. Most Indramayu women work to help increasing their family income by processing fishery products. These seafood products consists of fish meatball, shredded fish, fish paste, shrimp paste, fish crackers, shrimp crackers, fish nuggets, and others. Fish production can be categorized into creative economy since it uses people's creative imagination to increase the original value of fish. In food industry, fish are reprocessed into various types of products.
A total of 10 women from Indramayu subdistrict became informants in this study. Their age ranged from 30 to 45 . These women owned fish processing businesses. According to them, their skill to process fish are obtained from trainings provided by some agencies. They practised the knowledge they got from the trainings. Some succeeded and some failed, due to limited capital. The fish processed products that they produce in general are still in the form of preparations. These home industries are inherited from generation to generation. However, one of the informants, BT (an initial), who produced shrimp paste and fish paste, said that her bussiness only started from 2003. At first, she went through trials and errors in producing those pastes, but then it continued growing until now. Her shrimp paste production reaches 5 quintals in one production and she has around 20 employees. BT got help from her husband in marketing their shrimp paste producs. BT's shrimp paste is just like any others, coarse and wet, so that it will be quite costly when it is delivered. BT made an innovation of the existing preparations. The innovation resulted in a new creative economy: the dried shrimp paste. There was no dried shrimp paste sold at the moment in the market. The dried shrimp paste has been sold since the end of 2017 and has received positive responses from the community and her regular customers. The dried shrimp paste is ready to eat without further processing, while the previous shrimp paste is normally should be processed before consuming it. The new shrimp paste texture is dry and slightly smooth. Thus, shrimp connoisseurs can consume it directly in their food dishes.

Another informant in the production of fish processing is $\mathrm{TN}$, who produces shredded fish, along with other women who are 
members of the Batandu Abadi group, which was founded in 2012. The group consists of 9 women and is led by TN, who was the pioneer in her group business. She produces shredded fish production, especially shredded milkfish, which volumes reaches $50 \mathrm{~kg}$ per month. Even though her business is classified as a small business, with a capacity around $50 \mathrm{~kg}$ to 700 $\mathrm{kg}$ per month, TN attempts to market it widely. Actually, the market demand is high, but TN has not been able to serve it, due to several obstacles. Aside from shredded milkfish, TN also produces thornless milkfish (or banduri). On average, TN group produces around 1200 thornless milkfish per month. In running their business, TN also faces problems. These constraints include lack of manpower in producing shredded fish and banduri, pricey and poor packaging. She often faces big chalenges in marketing her products, until she is clueless as to where to sell them. However, TN still continues to run her business since she already committed herself in the group.

The two informants mentioned earlier were considered successful with their fish processing business. It can be inferred from the increasing amount of production each month. BT said that now she earns around 30 to 40 million rupiahs per month, compared to the previous profit, which was around 15 to 20 million rupiahs. Other informants reported much less production capacity. Therefore, the study will focus on the two informants.

The marketing of fish products is largely carried out traditionally, by selling them to local markets and loyal customers. Marketing has not been done in a modern way by utilizing ICT or the internet. Even though at this time more and more people are doing online transactions by buying products online, the two informants still market their products traditionally. The internet should be used by coastal women in marketing their products. The ten female informants basically know what is meant by the internet. In general, they define the internet as a source of information and entertainment. They knew about Google but they did not know exactly what Google is for. They all also knew about social media such as Facebook but they did not know how to use it. Some of them (especially BT and TN) knew about Instagram but they did not use it either. Only BT and TN used WhatsApp to share the information about their seafood production to her friends, customers and colleagues. The other informants did not know what WhatsApp is. The same applies to Instagram. The informants said that it is one of social media. They heard about social media, which they refer it to Facebook. When the researcher asked further what those social media were for, they said that those social media could not only be used to share pictures, obtain information, get connected to friends and family, but also to sell their products online.

Exploring further, these informants suggested that the internet allows them to get information and connect with others. It is interesting that these informants already have smartphones connected to the internet but they have not used the features and applications available on their smartphones. Unlike TN, BT uses Facebook to market her shrimp paste products. She posts pictures of shrimp paste and other products that she had on her Facebook account for online sales purposes. Unfortunately, she could not maintain the online marketing as she was preoccupied by managing her company and production. She did not have much time to update the information on her account. She also forgot her password so that online sales could not continue. With the new production of dried 
shrimp paste, BT intends to create an Instagram (IG) account to market the products. However, she is struggling with time limitations that she has.

BT's situation is different from TN. Although TN already knew about the internet, she is not skillful to use smartphone connected to internet. $\mathrm{TN}$ preferred to participate in various exhibitions, which were mostly held in Jakarta. From those exhibition activities, the sales of TN's products and her groups expanded. However, the market remained limited to local markets, such as Jakarta and West Java.

Meanwhile, other informants knew about the internet but have not used the internet through smartphones. Some of the obstacles faced by these women include lack of knowledge and skills in using internet (despite the fact that they finished high school), pricey internet connection, lack of spare time to learn about the internet, and the multiple roles that these women had to play.

Interestingly, literatures often suggest ICT as "important tools in poverty alleviation in a sustainable manner, in enhancing economic development and empowerment of marginalized sections of the population" (Ogan et al., 2009). This explanation shows that ICT can play a critical role in increasing economic development. Gunnstam and Nordquist (2009) stated that ICT can promote the economic growth of fishermen in Keralam India. The mobile phones used by the fishermen could increase the profit and at the same time lowered fish prices. Fishermen are sometimes clueless as to where to sell their fish when they have abundant catches. They have two choices to sell it, either selling it in traditional market or online (using internet and mobile phones). If they use the internet it will potentially expand their market. However, it will take a long time and the fish will be no longer fresh anymore so that they have to sell it with lower price.

This showed that fishermen could sell their product in other market that has higher demand by using mobile phones. This way, fishermen managed to increase their profits by $8 \%$ and lowered the consumer prices by $4 \%$ (Gunnstam \& Nordquist, 2009). While the research findings indicated that ICTs increase fishermen's profit, this study questioned whether ICTs could indeed improve the quality of life. As one of the informants (BT) argued that "the problem in using online marketing lies in the delivery fee. It is a bit expensive, so why should I do online if I already have regular customers? Online marketing might enlarge the market but the profit is not seen yet."

In other cases, according to Obijiofor (2015) with the existence of technology, this can assist middle-scale businesses to remove barriers in their business chains, as well as women. People can directly deal with their customers, which is the benefit of ICT in marketing. People do not need to meet and deal face to face, instead they can do it online. In addition, it is stated that ICT could assist in knowledge shariing for rural development (Pade-Khene, Mallinson \& Sewry, 2011). ICT can be used for promoting entrepreneurship and market access, enabling access to education and knowledge, addressing health challenges, rural empowerment, and participation etc. (Pade-Khene, Mallinson \& Sewry, 2011). Thus, ICT application for rural development has challenges, such as limited access to infrastructure, limited formal education, insufficient training and capacity building, financial and political constraints, and social and cultural challenges (PadeKhene, Mallinson \& Sewry, 2011). In 
Indramayu Regency, these obstacles include internet connections that have not been evenly distributed, internet infrastructure has not yet been developed and lack of access and skill of women (as indicated by the interview with Head of Planning and Evaluation of Communication and Information Office of Indramayu Regency, January 2018). In order to address those challenges, particularly for women, education, training and career development should focus on educating girls and women to be media and ICT-literate, train more women in mass communication sector and promote more and more women to hold decision-making positions in business and governmental institutions. In the infrastructure sector, the concerns are to provide all women with access to the media and ICT they wish to use and develop communication and information networks that benefit women (Jensen, 2006). It is necessary to improve women's participation in Indramayu subdistrict as women need to be empowered through ICT. Empowering women through ICT has been touted since Tokyo Declaration of the Asia-Pacific Regional Conference for World Summit on the Information Society (WSIS) 2003 stating that the quality of women can be improved by empowering women through ICT so that women can participate in the fields of politics, economics and social development (Wanasundera, 2006).

Women should be encouraged to be able to use ICT and have an equal opportunity to access it. In adopting ICT, especially the internet, women face various obstacles. Village women will face problem of connectivity, cost and education as well as time to use it. These issues were reported by all informants. It is indeed a complicated task to encourage village women to get connected through the internet. Therefore, the informants stated that the local government should provide assistance and encourage people to use the internet. Women's voices should be heard in order to participate in sustainable development.

With regard to ICT and the creative economy discussed throughout this paper, it can be said that this has not been properly implemented. However, these women were interested in learning ICT. Unfortunately, they were not supported by adequate facilities and infrastructure. This is consistent with many literatures stating that women face many barriers such as income, education and accessibility and also the development of ICT itself. Women look for assistance from the government in promoting creative economy and the use of ICT.

\section{CONCLUSION AND RECOMMENDATION}

The term 'creative economy' in this study refers to women's fish processing production. Unfortunately, this creativity is yet supported by ICTs (the internet), especially women who have small scale production, which accounted for around $50 \mathrm{~kg}$ to $700 \mathrm{~kg}$ per month. In fact, even though some women generate larger amounts of production, they were unskillful to use the internet in assisting their business. Women face many kinds of barriers in utilizing the internet due to lower level of knowledge and skills, expensive cost for internet connection, lack of time to learn about the internet, and the multiple roles women have.

The Ministry of Marine and Fisheries that are directly related to fisheries production activities should pay more attention to women's need in term of fish production. The local government needs to take a collaboration with the Ministry of Communication and Information Technology to improve the 
quality of internet infrastructure and literacy rates among women. All of these efforts are expected to empower women using ICT particularly the internet. Media literacy is critical to help women to be more skillful and broaden their mind. Ultimately, literate women are expected to be treated equal as men, and will contribute more to their community.

\section{ACKNOWLEDGEMENT}

The researcher would like to thank to the Ministry of Research and Technology and Higher Education of Indonesia for funding this research, the Marine and Fisheries Office of the Indramayu regency administration for providing information needed, the instructors and the informants for giving their valuable time to participate in the discussion with the researcher.

\section{REFERENCES}

Abiodun, O.O. \& Sunday, A.I. (2013). Poverty Alleviation through Information and Communications Technology: A Case Study of Nigeria. International Journal of Multidisciplinary Sciences and Engineering 4(7):20-24.

Afiff F. (2012). Pilar-pilar Ekonomi Kreatif. Rangkaian Kolom Kluster I. Accessed on 10 December 2018 from http://sbm.binus.ac.id/files/2013/04/Pilar -Pilar-Ekonomi-Kreatif.pdf.

Badan Ekonomi Kreatif. (2017). Data Statistik dan Hasil Survei Ekonomi Kreatif. Jakarta: Badan Ekonomi Kreatif.

Badan Pusat Statistik (BPS) Provinsi Jawa Barat. (2017). Sumbangan Pendapatan Perempuan Menurut Kabupaten/Kota di Jawa Barat (\%), 2014-2015. Jawa Barat: Badan Pusat Statistik Provinsi Jawa Barat.
Djauhari M. (2011). Pemberdayaan Infrastruktur Tik Dalam Mendorong Perekonomian Masyarakat Miskin Di Perdesaan. Buletin Pos dan Telekomunikasi 9(1): 1-22.

Dinas Kelautan dan Perikanan Jawa Barat. (2017). Data Jumlah Produksi Olahan 2014-2016. Jawa Barat: Dinas Kelautan dan Perikanan Jawa Barat.

Gary. (2016). Peran ekonomi kreatif terhadap pertumbuhan ekonomi nasional. Accesed on 10 June 2018 from https://beritagar.id/artikel/infografik/pera n-ekonomi-kreatif-terhadappertumbuhan-ekonomi-nasional).

Gunnstam, C. \& Nordquist, C.J. (2009). A Study of the Sustainability of ICTprojects in Developing Countries. Thesis, unpublished. Thesis. Department of Industrial Management \& Logistics Faculty of Engineering, Lund: Lund University.

Hashim, F., Amir, Z., \& Razak, N A. (2011). Empowering Rural Women Entrepreneurs with ICT Skills: An Impact Study. Procedia Social and Behavioral Sciences 15:3369-3373.

Hikmah, I. (2009). Pemberdayaan Peran Perempuan Nelayan Melalui Pengembangan Usaha Ekonomi Produktif dalam Dinamika Peran Gender dan Diseminasi Inovasi. Jakarta: Balai Besar Riset Sosial Ekonomi Kelautan dan Perikanan.

Hilbert, M. (2011). Digital gender divide or technologically empowered women in developing countries? A typical case of lies, damned lies, and statistic. Women's Studies International Forum 34:479-489. Jensen, H. (2006). Women, Media and ICTs in UN Politics: Progress or Backlash?.Gender in the Information 
Society. Bangkok:UNDP Asia-Pacific Development Information Programme.

Kominfo. (2018). Jumlah Pengguna Internet 2017 Meningkat, Kominfo Terus Lakukan Percepatan Pembangunan Broadband. Accesed on 10 December 2018 from https://kominfo.go.id/index.php/content/ detail/12640/siaran-pers-no-

53hmkominfo022018 tentang-jumlahpengguna-internet-2017-meningkat-

kominfo-terus-lakukan-percepatan-

pembangunan-broadband/0/siaran_pers.

Kwapong O., Adwoa T F. (2007). Problems of policy formulation and implementation: the case of ICT use in rural women's empowerment in Ghana. International Journal of Education and Development using Information and Communication Technology (IJEDICT) 3(2): 41-61.

Nath V. (2001). Empowerment and Governance through Information and Communication Technologies: Women's Perspective. Journal International Information and Library Review 33:317339

Obijiofor, L. (2015). New Technologies in Developing Societies. New York: Palgrave Macmillan.
Ogan C.L., Bashir, M., et al. (2009). Development Communication: The state of Research in an Era of ICTs and Globalization. The International Communication Gazette 71(8): 655-670.

Pade-Khene, Mallinson. \& Sewry. (2011). Sustainable rural ICT project management practice for developing countries: investigating the Dwesa and RUMEP projects. Information Technology for Development 17(3): 187212.

Purnomo, R.A. (2016). Ekonomi Kreatif Pilar Pembangunan Indonesia. Jakarta:www.nulisbuku.com.

Tiwari, M. (2008). ICTs and poverty reduction: user perspective study of rural Madhya Pradesh, India. The European Journal of Development Research 20(3): 448-461.

Wanasundera, L. (2006). Expanding Women's Capacities through Access to ICTs: An Overview from Sri Lanka. Gender in the Information Society. Bangkok: UNDP Asia-Pacific Development Information Programme. 